Przemysław Nowakowski CM, Ikona w liturgii, liturgia na ikonie. O ikonie w przestrzeni sakralnej, w: Przestrzeń liturgiczna, red. Adelajda Sielepin CHR, Jarosław Superson SAC, Kraków 2019, s. 181-207.

DOI: http://dx.doi.org/10.15633/9788374387828.09

\title{
Ikona w liturgii, liturgia na ikonie. O ikonie w przestrzeni sakralnej
}

Z okazji jubileuszu 2000 lat chrześcijaństwa, w Pałacu Apostolskim w Watykanie, pod koniec lat dziewięćdziesiątych ubiegłego wieku, powstała kaplica Redemptoris Mater - dar kolegium kardynalskiego na 50-lecie kapłaństwa papieża Jana Pawła II. Została ona wykonana przez artystów Centrum Aletti (Centro Aletti) pod kierunkiem jezuitów Tomáša Špidlíka i Marka Rupnika, związanych z Papieskim Instytutem Wschodnim w Rzymie. W swoich pracach, które inspirują się starożytną sztuką mozaiki, artyści ci nawiązują często do ikonografii Kościołów wschodnich, zwłaszcza tradycji bizantyjskiej. W artystyczno-teologicznym projekcie kaplicy Redemptoris Mater wziął udział także artysta rosyjski Aleksander Kornouchow, specjalizujący się w technice mozaiki'.

Na centralnej ścianie kaplicy, pełniącej funkcję absydy i będącej tłem dla ołtarza, Kornouchow stworzył dzieło wyrażające ideę jedności chrześcijaństwa, która swoją pełnię osiągnie w królestwie Bożym, gdzie połączy się świętość Wschodu i Zachodu. Artysta przedstawił obraz niebieskiego Jeruzalem, w którego murach umieścił świętych wschodnich i zachodnich. Przy stołach uczty niebieskiej zasiadają razem św. Franciszek i św. Serafin Sarowski, św. Tomasz i św. Grzegorz Palamas, św. Bazyli i św. Augustyn... Głównym tematem mozaiki szkoły o. Rupnika, rozwijającym się w bardziej dynamicznym tempie, jest powtórne przyjście Chrystusa na ziemię (ściana zachodnia), które wieńczy całe dzieje zbawcze od wcielenia i Paschy (ściana południowa) poprzez wniebowstąpienie i zesłanie Ducha Świętego (ściana północna), wciągające

I Por. I. Jazykowa, Oto czynię wszystko nowe. Ikona w XX wieku, Warszawa 20II, s. I88-I89. 
w swój bieg ludzi wszystkich czasów (są przedstawieni wybrani święci, dawni i współcześni, jak np. św. Jan Paweł II, ale także twórcy mozaiki, wśród nich Špidlík, Rupnik i zwykli ludzie - kochająca się para ludzka, dziecko). W ten zbawczy ruch, który bardzo wymownie wyrażony jest na mozaice, włączony zostaje każdy, kto znajdzie się wewnątrz kaplicy².

Uczestnikami tego ruchu stają się zwłaszcza ci, którzy będą w tym miejscu brać udział w liturgii. Ikonograficzny program kaplicy jest wyraźnie stworzony dla potrzeb liturgii, która ma być w niej sprawowana i znajdować ilustrację misterium na otaczających zgromadzenie mozaikach. Ołtarz Eucharystii wyłania się na tle mozaiki Jerozolimy niebieskiej, którą w tej przestrzeni sakralnej można porównać do ikonostasu. Miejsce przewodniczenia (tron papieski) znajduje się przy ścianie zachodniej u stóp Chrystusa w chwale Paruzji, a ambona słowa Bożego - na środku kaplicy33.

Dwie wizje artystyczne (Kornouchowa i Rupnika), chociaż zasadniczo różnią się między sobą - stylem, środkami wyrazu, dynamiką - stanowią jednak ciekawe pojednanie artystycznych poszukiwań współczesnych artystów, nawiązujących do starożytnej sztuki ikony, która zdobywa sobie wielką popularność także na zachodzie Europy i jest być może jedną z szans odrodzenia autentycznej sztuki religijnej, przeżywającej dziś poważny kryzys.

\section{IKONA SAKRAMENTEM OBECNOŚCI}

Bez wątpienia to właśnie ikona kojarzy nam się najbardziej z modlitewną i liturgiczną tradycją Kościołów wschodnich. Z uwagi na funkcje, które pełni (zostaną wyjaśnione poniżej), ma przede wszystkim charakter teologiczny, stwierdza Ilarion Alfejev, metropolita Wołokołamska, odpowiedzialny w Patriarchacie Moskiewskim za relacje z zagranicą ${ }^{4}$.

\footnotetext{
2 Autor artykułu miał okazję osobiście tego doświadczyć, zwiedzając kaplicę Redmptoris Mater pod koniec stycznia 2018 roku, dzięki uprzejmości ks. Pawła Ptasznika z Sekcji Polskiej Sekretariatu Stanu Stolicy Apostolskiej.

3 Nota bene, tak liturgicznie uzasadniony układ kaplicy został niestety zmieniony za czasów papieża Benedykta XVI wbrew intencjom jej twórców. Do wnętrza wstawiono ławki (fotele), tron papieski i ambonkę przeniesiono do przestrzeni ołtarzowej przy ścianie wschodniej.

4 Por. I. Alfeev, L'icona. Arte, bellezza e mistero, Bologna 20I7, s. I22-I25.
} 
Niezwykła popularność i kult ikon w Kościele bizantyjskim doprowadziły tam w VII i VIII wieku do dyskusji, która przekroczyła ramy intelektualne i zamieniła się w otwartą walkę z ikonami, nazwaną ikonoklazmem. W wyniku tej kontrowersji, na drugim soborze nicejskim (787) ustalone zostały teologiczne podstawy i uzasadnienie możliwości wykonywania obrazów Chrystusa i świętych w oparciu o tajemnicę wcielenia5. Ostatni grecki ojciec Kościoła, św. Jan Damasceński, nauczał:

W dawnych czasach Bóg, który nie ma ciała ani kształtu, nie mógł być w żaden sposób przedstawiany. Teraz jednak, skoro stał się widzialny w ciele, przedstawiam wizerunki Boga, którego widzę ${ }^{6}$.

Tajemnica wcielenia nie tylko zezwala na „pisanie” ikon, ale sama jest w pewien sposób realizowana dalej w ikonach. Pisze o tym Nicola Bux w swojej najnowszej książce poświęconej liturgii w obrządkach wschodnich pt. Między niebem a ziemia (Tra cielo e terra), dodając jeszcze jeden aspekt teologiczny ikony - eschatologię ${ }^{7}$. Według autora zatem teologia ikony przedstawia syntezę dwóch tendencji, które zdominowały historię chrześcijaństwa - wcielenia i eschatologii:

Ikona kontynuuje wcielone objawienie Słowa, które stało się ciałem i całej przemienionej ludzkości (wcielenie); ale równocześnie chce być obrazem całkowitej i definitywnej przemiany (eschatologia). Wzorem każdej celebracji liturgicznej, ikona to misterium, znak wyższej rzeczywistości, z którą ikona łączy człowieka ${ }^{8}$.

W świetle tej nauki o ikonie jej głównym zadaniem jest objawianie misteriów królestwa Bożego. Dokonuje się to przede wszystkim podczas liturgii, która stanowi przedstawienie i reprezentację (przedstawienie na nowo) ziemskiego dzieła zbawienia dokonanego przez Chrystusa9. Takie pojmowanie liturgii dostrzegamy u św. Symeona z Tessalonik, który w swoim dziele o sakramentach pisze:

\footnotetext{
5 Por. J. Meyendorff, Teologia bizantyjska, Warszawa I984, s. 60-6I.

6 Jan Damasceński, I Mowa obronna przeciw tym, którzy odrzucaja święte obrazy, I6, thum. M. Dylewska, „Vox Patrum” I9 (I999) t. 36-37, s. 507.

7 N. Bux, Tra cielo e terra. La mistica della liturgia orientale, Siena 20I7, s. 209-2I0.

8 N. Bux, Tra cielo e terra..., dz. cyt., s. 2 Iо.

9 Por. R. Taft, Liturgia. Wzór modlitwy, ikona życia, Warszawa 20Io, s. 83.
} 
Jezus, który jest bezcielesny, niewysłowiony i niepojęty, ale który dla nas przyjął ciało i stając się możliwy do pojęcia, ukazał się na ziemi i zaczął przebywać wśród ludzi (Ba 3, 38), pozostając Bogiem, żeby uświęcić nas w dwojakiej formie, wedle tego, co niewidzialne i tego, co widzialne. Przekazał nam też sakramenty w dwojakiej formie, jednocześnie materialnej i widzialnej dla naszego ciała, a także mistycznej, napełnionej niewidzialną łaską dla naszej duszy ${ }^{\mathrm{I}}$.

Ikona w tradycji wschodniej uważana jest za ósmy sakrament i nazywana „oknem do innego świata”. W liturgii obrządku wschodniego ikona nie jest więc zwykłym przedmiotem kultu, ale „,sakramentem Bożej obecności”"II. Cerkiew, wypełniona ikonami, gdzie liturgię się celebruje, ,jest niebem na ziemi, w którym Bóg nieba mieszka i porusza sięe"ı2:

Dlatego najskromniejszy wiejski kościółek jest „,niebem na ziemi”, w którym można „odłożyć wszelką życia troskę” - jak mówią słowa Hymnu cherubinów „,abyśmy przyjęli Króla wszystkich”³.

Podstawową funkcją ikony nie jest więc wierne odtwarzanie obrazu rzeczy niewidzialnych, ale ich uobecnianie. Wedle słów św. Jana Damasceńskiego ikony są „kanałami łaski o uświęcającej mocy”. Każda ikona pełni funkcję ikony Zbawiciela, zwanej Archeiopoieti (nie ręką ludzką uczynioną) - jest ikoną Jego obecności ${ }^{14}$. Jeden z największych ikonopisarzy rosyjskich ubiegłego wieku, zwany drugim Andrzejem Rublowem, o. Grigorij Krug (I908-I969) ${ }^{15}$ tak pisze na ten temat:

To właśnie Chrystus w swoim Wcieleniu odnowił Boży obraz w człowieku, a nawet więcej - stał się pełnym i doskonałym urzeczywistnieniem Bożego

\footnotetext{
Io Symeon Thessalonicensis Arhiepiscopus, De sacro ritu sancti olei, w: Symeonis Thessalonicensis Archiepiscopi Opera Omnia, tomus unicus, accurante J.-P. Migne, Parisiis I886, kol. 545D-525A (Patrologiae Cursus Completus Series Graeca [dalej: PG], I55).

II N. Bux, Tra cielo e terra ..., dz. cyt., s. 2IO.

12 German z Konstantynopola, On the Divine Liturgy, Crestwood I984, s. 56.

13 R. Taft, Liturgia..., dz. cyt., s. 85 .

${ }^{14}$ Por. P. Nowakowski, Liturgiczna funkcja ikony w obrzadku bizantyjskim, „Liturgia Sacra” IO (2004), s. 3I4.

15 O życiu i twórczości G. Kruga zob. I. Jazykowa, Oto czynię wszystko nowe..., dz. cyt., s. $44-53$.
} 
obrazu, ikoną ikon, źródłem wszelkiego świętego wyobrażenia, obrazem nie ręka ludzka uczynionym, żywym Jeruzalem ${ }^{16}$.

Uobecniającą funkcję ikony Paweł Floreński porównuje do okna:

Okno spełnia swoje zadanie, kiedy przekazuje światło. Jest to możliwe tylko wtedy, gdy za nim rozpościera się obszar światła. Wówczas okno nie jest czymś podobnym do światła, lecz jakby samym światłem, niepodzielnym w sobie i nieodłącznym od słońca, które świeci zewnętrznej przestrzeni. W oderwaniu od światła poza swą funkcją, okno jest martwe i nie jest oknem, to tylko drzewo i szkło. Podobnie ikona oderwana od duchowego widzenia, z którym się pokrywa, nie jest ani obrazem, ani ikoną, lecz tylko deską ${ }^{17}$.

\section{IKONA OBJAWIENIEM DOGMATU I ŹRÓDŁEM MODLITWY}

Z funkcją uobecniającą wiąże się dydaktyczna, nauczająca funkcja ikony. Można by zaryzykować stwierdzenie, że to obecni przez ikonę Zbawiciel i święci kontynuują dalej swoje nauczanie przez „malowane słowa” i plastycznie ukazywane przykłady z ich życia. Na ikonach Kościół w symboliczny sposób ukazywał prawdy wiary, wypracowane na swoich soborach. Słynne i często przytaczane w tym kontekście są słowa św. Jana Damasceńskiego:

Jeśli poganin pyta się o twoją wiarę, zaprowadź go do kościoła i postaw przed świętymi ikonami ${ }^{18}$.

Z racji tego, że ikona przekazuje wiernym najważniejsze prawdy o Bogu jest swoistą , wizją dogmatu”, tworzona jest zawsze według ustalonych przez Cerkiew kanonów. Łączy w sobie i spełnia zatem podwójną funkcję: zbliża wiernych do Boga, stawia ich w tajemnicy Jego obecności i objawia Go w świetle całej prawdy:

\footnotetext{
I6 G. Krug, Myśli o ikonie, Białystok I99I, s. I2.

${ }_{17}$ P. Florenski, Ikonostas $i$ inne szkice, Warszawa I984, S. I22-I23.

I8 Jan Damasceński, I Mowa obronna..., dz. cyt., s. 507.
} 
Ikona jest hymnem pochwalnym, doksologią, potokiem chwały, którą śpiewa za pomocą sobie właściwych środków. Prawdziwe piękno nie ma potrzeby udowadniania siebie, jest ono oczywistością podniesioną na płaszczyznę ikonograficznego argumentu na rzecz Prawdy Bożej. Poznawcza treść ikon jest dogmatyczna, dlatego nie ikona jako dzieło sztuki jest piękna, lecz przede wszystkim jej prawda ${ }^{19}$.

Ikona jako połączenie prawdy i wynikającego z niej piękna, prowadząca do spotkania z Bogiem w Jego obecności staje się modlitwą, która wychwala i wielbi Boga w prawdach nam objawionych i dziełach zrealizowanych dla naszego zbawienia. Evegenij Trubeckoj nazwie ją z tego powodu „kolorową kontemplacją"20.

Dokonując wyczerpującego przeglądu twórczości współczesnych ikonografów z Rosji i spoza jej granic, Irina Jazykowa stwierdza:

Ikonografia jest sztuką kanonu, ściśle reglamentującą pracę ikonografia, co chroni od wielu pokus, ale nie zwalnia z twórczości [...]. Autentyczny ikonograf postrzega w kanonie kanał, który wiąże go z tradycją i równocześnie otwiera przed nim możliwości stworzenia nowego obrazu. A także to, że ikona jest modlitwą, a modlitwa, nawet przy powtarzaniu tych samych słów, za każdym razem jest inna, nowa, otwiera przed nami nowy poziom wspólnoty z Bogiem ${ }^{21}$.

Ikona, która jest rodzajem modlitwy, sama rodzi się z modlitwy i bez niej nie może być autentyczna. Uznawany za najwybitniejszego współczesnego ikonopisarza w Rosji archimandryta Zinon (Teodor) mówi:

Ikona jest wcieloną modlitwą. Zostaje stworzona z modlitwy i dla modlitwy, jej motoryczną siłą jest miłość Boga, dążenie do Niego jako doskonałego Piękna ${ }^{22}$.

Będąc owocem modlitwy, ikona jest także szkołą modlitwy dla tych, którzy ją kontemplują, modląc się przed nią. Jednocześnie modlitwa przenosi wiernego poza ikonę, stawiając go przed samym archetypem - Jezusem Chrystusem, Matką Bożą, czy też przed jakimś świętym. Formułując tę myśl,

\footnotetext{
I9 P. Evdokimov, Prawostawie, Warszawa 1986, s. 277.

20 Zob. E. Trubeckoi, Contemplazione nel colore. Tre studi sull'icona russa, Milano 1988.

${ }_{21}$ I. Jazykowa, Oto czynię wszystko nowe..., dz. cyt., s. I22.

22 Archimandrit Zinon (Teodor), Biesiedy ikonopisca, Riga I997, s. I44.
} 
Ilarion Alfejev podaje przykłady, znane w tradycji duchowości prawosławnej, kiedy niektórzy modlący się przed ikoną, „widzieli na żywo” (mieli wizję) tego, kogo ona wyobrażała. Tak było w przypadku św. Sylwana, starca z góry Athos, który podczas celebracji nieszporów, przy ikonie Chrystusa (na prawo od „bramy królewskiej” ikonostasu) miał ujrzeć żywego Zbawiciela ${ }^{23}$.

Wyżej ukazane teologiczne znaczenie ikony i jej funkcje w życiu Kościoła bizantyjskiego dobrze wyjaśniają twierdzenie, że ikona najpełniej ,realizuje swoje powołanie" w liturgii. Liturgia jest bowiem miejscem obecności Boga i Jego aktualnego oddziaływania na ludzi (ikona sakramentem obecności), wyrazem wiary i nauczania Kościoła (ikona objawieniem dogmatu) oraz wspólnotową, kościelną modlitwą (ikona źródłem modlitwy). Poniżej ukażemy ten ważny związek ikony z liturgią obrządku wschodniego, która jest jego nieodłączną częścią. Zobaczymy także, jak liturgia wpływa na ikonę determinuje jej kształt i tematykę. Okazuje się, że przemyślenie i odnowienie tej problematyki jest ważne także dla środowiska prawosławnego. Świadczą o tym następujące, krytyczne słowa ojca Zinona:

Można powiedzieć, że teraz ikona nie zajmuje w liturgii należnego jej miejsca i stosunek do niej nie jest taki, jaki powinien być. Ikona stała się po prostu ilustracją obchodzonego święta i z tego powodu nie przywiązuje się znaczenia do jej formy. Dlatego też u nas każde przedstawienie, nawet fotograficzne, jest czczone jako ikona. Na ikonę już dawno temu przestano patrzeć, jak na teologię w kolorach, nie podejrzewając, że podobnie jak błędne słowa, może ona wypaczyć przekaz wiary. Zamiast świadczyć o Prawdzie, ikona może świadczyć o fałszu ${ }^{24}$.

\section{LITURGIA JAKO IKONA}

Liturgia bizantyjska realizuje ideę „liturgii niebieskiej”, tzn. sprawowaną na ziemi liturgię traktuje się jako odbicie prawdziwej liturgii, która odbywa się w niebieskim mieście Jeruzalem, gdzie sam Chrystus „siedzi po prawicy

\footnotetext{
23 Por. I. Alfeev, L'icona..., dz. cyt., s. I44-I45.

24 Archimandrit Zinon (Teodor), Biesiedy ikonopisca, dz. cyt., s. I28-I29.
} 
Bożej jako sługa świątyni i prawdziwego przybytku”"25, otoczony rzeszą aniołów i świętych, śpiewających Bogu pieśn chwały. Innymi słowy liturgia ziemska jest obrazem, „ikoną” liturgii niebieskiej. Robert Taft pisze o „ikonograficznym” charakterze liturgii obrządku wschodniego. $Z$ tego powodu akcja liturgiczna jest czymś więcej niż zwykłą ceremonią, sama staje się przedmiotem kontemplacji, wspaniałą wizją przepełnioną tajemnicą ${ }^{26}$. W teologii patrystycznej obrzędy liturgiczne stanowiły równocześnie przedstawienie - reprezentację i aktualizację ziemskiego dzieła Jezusa (z przeszłości), a także Jego chwały niebieskiej (z teraźniejszości) i paruzji (z przyszłości), łącząc w jedną wspólnotę Kościół ziemski i niebieski:

Jeden i ten sam Kościół istnieje w górze i na dole, gdyż Bóg pojawił się wśród nas i był widziany w naszym kształcie [...]. Kapłańskie działania Pana, komunia i kontemplacja stanowią jedno dzieło, które dokonuje się jednocześnie w górze i tu na dole, z tą różnicą, że tam w górze bez zasłon i symboli, zaś tutaj - przez symbole $[\ldots]^{27}$.

Wśród tych symboli bardzo ważne miejsce zajmują ikony, wypełniające sakralną przestrzeń cerkwi. Cała świątynia jest zaprojektowana tak, aby wzmocnić tę „wielowarstwową neoplatońską wizję tajemnicy”28. Składa się na nią zarówno plan budynku, jak i program ikonograficzny cerkwi. Chodzi więc tu nie tylko o pojedyncze ikony, umieszczone w odpowiednich miejscach (np. na ikonostasie), lecz także o pokryte mozaiką lub freskami ściany cerkwi. Wszystko wykonane jest według ściśle przestrzeganych, tradycyjnych wzorców - kanonu, podobnie jak ma to miejsce w przypadku pojedynczej ikony ${ }^{29}$ :

W wystroju świątyni różnorodne ikonograficzne sceny i postacie nie pojawiają się przypadkowo, lecz uporządkowane są wedle określonego teologicznego schematu tak, aby cała budowla świątyni stanowiła jedną wielką ikonę, wyobrażenie Królestwa Bożego. Podobnie jak niegdyś w sztuce średniowiecznego

\footnotetext{
25 Sobór Watykański II, Konstytucja o świętej liturgii Sacrosanctum Concilium, nr 8. Cytowany w tekście numer konstytucji Sacrosanctum Concilium inspirowany jest wschodnią teologią liturgiczną.

26 Por. R. Taft, Liturgia ..., dz. cyt., s. 85 .

27 R. Taft, Liturgia ..., dz. cyt., s. 84 .

28 R. Taft, Liturgia..., dz. cyt., s. 86.

29 Por. N. Bux, Tra cielo e terra ..., dz. cyt., s. 209.
} 
Zachodu, w prawosławnej sztuce sakralnej przejawia się wyszukany system symboli, ogarniający każdą część świątyni. Ikony, freski, mozaiki nie są jedynie dekoracjami, wprowadzanymi po to, aby cerkiew „ładnie wyglądała”, ale odgrywają ważną rolę teologiczną i liturgicznąa ${ }^{30}$.

Plan cerkwi, naśladując układ świątyni jerozolimskiej, podzielony jest na trzy części: część ołtarzowa (ros. ałtar, odpowiednik rzymskiego prezbiterium), nawa (grec. naos) i przedsionek (ros. pritwor). Część ołtarzowa, oddzielona od nawy ikonostasem symbolizuje niebo. Mogą w niej przebywać tylko kapłani i posługujący podczas liturgii. Wierni zajmują miejsce w nawie, która oznacza rzeczywistość ziemską Kościoła. Katechumeni i pokutujący zatrzymywali się kiedyś w przedsionku, oczekując na wprowadzenie do Kościoła ${ }^{31}$.

Program ikonograficzny świątyni ukazywał świat stworzony, świat człowieka i historię jego zbawienia ${ }^{32}$. Z wysokości kopuły spogląda na wiernych surowe oblicze Wszechmogącego (Pantokratora) w otoczeniu aniołów i świętych. Wierni zwracają się obliczem na wschód, w stronę ołtarza, gdzie odnajdują swoim wzrokiem Chrystusa, Matkę Bożą i świętych - mieszkańców nieba przedstawionych na ikonostasie. O ile na wschodniej ścianie i na ikonostasie ukazane są sceny odnoszące się do zbawienia i Królestwa Bożego, o tyle ściana zachodnia odsłania prawdę o końcu świata i sądzie, czekającym na człowieka po śmierci (scena Strasznego sądu, czyli Sąu ostatecznego). $\mathrm{Na}$ ścianach bocznych i sklepieniach umieszcza się sceny biblijne, ze Starego i Nowego Testamentu, z życia Bogurodzicy i świętych oraz sceny z życia Kościoła podczas jego ziemskiej historii ${ }^{33}$. W ten sposób wierny, jak pisze ojciec Aleksander Mień, „swoją przynależność do Kościoła, zarówno widzialnego, jak i niewidzialnego odczuwał niemalże od chwili przekroczenia progu cerkwi"'34.

Tak liturgicznie ukształtowana przestrzeń cerkwi wraz z jej ikonografią skutecznie wspomaga sprawowanie kultu na ziemi, który jawi się jako ikona liturgii niebieskiej. Współcześni prawosławni mogą więc, tak jak przed wie-

\footnotetext{
30 K. Ware, Kościót prawosławny, Białystok 2002, s. 300-30I.

${ }^{3}$ Por. A. Mień, Sakrament, słowo, obrzęd. Prawosławna stużba Boża, Łuków 1992, s. I8-20.

32 Por. N. Bux, Tra cielo e terra ..., dz. cyt., s. I89-20I.

33 Por. A. Mień, Sakrament, słowo, obrzęd..., dz. cyt., s. I7. Zob. też I. Jazykowa, Świat ikony, Warszawa I988, s. 50-52.

34 A. Mień, Sakrament, stowo, obrzęd..., dz. cyt., s. I8.
} 
kami wysłannicy księcia Rusi Kijowskiej Włodzimierza ${ }^{35}$, czuć się w cerkwi uczestnikami liturgii nieba:

Ikony, które wypełniają cerkiew, są punktami styczności pomiędzy niebem a ziemią. Gdy podczas Boskiej Liturgii każda lokalna wspólnota modli się co niedziela w otoczeniu wyobrażeń Chrystusa, aniołów i świętych, te widzialne obrazy nieustannie przypominają jej o niewidzialnej obecności całego świata niebios. Wierni odczuwają, że ściany cerkwi otwierają się na wieczność, co pomaga im zrozumieć, iż celebrowana tutaj na ziemi Liturgia jest tożsama ze wspaniałą Liturgią niebios. Niezliczone ikony wyrażają pojęcie „nieba na ziemi” ${ }^{36}$.

Źródła takiego podejścia prawosławia do liturgii Taft widzi w teologii patrystycznej:

Wschodni chrześcijanie, odśpiewując w takiej atmosferze liturgię, gdy chmury kadzidła wznoszą się wraz z modlitwami ku Chrystusowi - Pantokratorowi wyobrażonemu na kopule, znajdują się w świecie Ojców Kościoła. To ich teologia, głosząca, że widzialne stworzenie jest symbolem niewidzialnego, że Wcielenie Chrystusa odnowiło w ludzkości obraz Boskiego piękna, znajduje się w sercu bizantyjskiego ducha liturgii i estetyki ${ }^{37}$.

Myśl ojców Kościoła o liturgii kontynuowały starożytne komentarze bizantyjskie do liturgii, których dalszym echem są pisma św. Symeona z Tessaloniki (XV wiek), podkreślającego bardzo często jej podwójny, ikoniczny charakter - ziemski i niebieski:

Cerkiew, jako dom Boży, jest obrazem całego świata, gdyż Bóg jest wszędzie i ponad wszystkim [...]. Część ołtarzowa symbolizuje sfery wyższe i po-

35 Kniaź Włodzimierz, rozważając jaką religię przyjąć dla swojego państwa, miał wysłać swoich posłów, aby sprawdzili, jak różne ludy modlą się do Boga. Najbardziej zachwyciła ich liturgia sprawowana przez bizantyjczyków w soborze „Haghia Sophia” w Konstantynopolu. Tak o niej mówili po powrocie do Kijowa: „Poszliśmy zatem do Greków, którzy zaprowadzili nas tam, gdzie oddają cześć swemu Bogu. I nie wiedzieliśmy już, czy jesteśmy w niebie, czy na ziemi. Na ziemi bowiem nie ma takiego widowiska, ani takiego piękna; nie jesteśmy w stanie go wyrazić. Ale wiemy tylko, że to tam Bóg mieszka z ludźmi i że ich kult przewyższa ten, jaki sprawuje się w innych krajach" (Povest'vremennych let, red. A. Lichaczev, t. I, Moskva-Leningrad I930, s. 74).

$3^{6}$ K. Ware, Kościót prawosławny, dz. cyt., s. 30 I.

37 R. Taft, Ponad wschodem i zachodem. Problemy rozumienia liturgii, Kraków 20I4, s. 202. 
nadniebiańskie, gdzie ma zamieszkiwać Bóg i gdzie znajduje się Jego tron. Ołtarz reprezentuje właśnie ów tron. Niebiańskie hierarchie ukazane są w wielu miejscach, lecz tu dołączają się do nich reprezentujący je kapłani. Biskup reprezentuje Chrystusa, cerkiew reprezentuje świat widzialny [...]. Poza nią znajdują się sfey niższe i świat tych stworzeń, które nie żyją rozumnie i które nie mają w sobie wywyższonego życia [...]. Bóg zstąpił na ten świat, żył między nami, czyniąc w naszym imieniu to, na co został posłany. I dokonywane jest jedno dzieło, tak jak jedna jest ofiara, komunia i kontemplacja naszego Pana. I wykonuje się je zarówno w niebiosach, jak tu na ziemi, lecz z tą różnicą: tam czynione jest to bez żadnych zasłon czy symboli, lecz tutaj osiąga się je poprzez symbole, gdyż my, ludzie, obciążeni jesteśmy ciałem, które podlega zepsuciu $^{38}$.

\section{IKONA W LITURGII}

Z przedstawionych wyżej fundamentów teologii ikony wynika jednoznacznie, że w Kościele tradycji wschodniej pełni ona przede wszystkim funkcję liturgiczną: jest niezbędnym elementem cerkwi i przestrzeni sakralnej oraz nieodzowną częścią liturgicznej celebracji - uczestniczy w niej, wręcz tak jak żywe osoby - kapłani i wierni ${ }^{39}$. Ojciec Gabriel Bunge pisze:

Ikona ze swej natury nie jest przeznaczona dla prywatnej pobożności. Jej locus teologicus jest raczej liturgia, gdzie ikona dopełnia głoszenie słowa głoszeniem obrazu $^{40}$.

Jeden z prawosławnych liturgistów stwierdza, że o ile indywidualna modlitwa wynika z pobożności, o tyle modlitwa liturgiczna wynika z całości prawdy. Tę prawdę „głosi” także występująca w liturgii ikona.

\footnotetext{
${ }^{38}$ Symeon Thessalonicensis Arhiepiscopus, De sacro templo et eius consecratione, w: Symeonis Thessalonicensis Archiepiscopi Opera Omnia, dz. cyt., kol. 337-340 (PG I55).

39 Por. P. Nowakowski, Liturgiczna funkcja ikony..., dz. cyt., s. 320-326.

$4^{\circ}$ G. Bunge, Lo Spirito Consolatore. Il significato dell'iconografia della Santa Trinità dalle catacombe a Rublev, Milano I995, s. 93.
} 
Ikona bierze udział w akcji liturgicznej razem z ewangeliarzem i innymi paramentami. Podobnie jak ewangeliarz, jest okadzana i całowana; przed ikonami wierni kłaniają się i zapalają świeczki na znak czci oraz jako symbol próśb zanoszonych do Chrystusa, Bogurodzicy czy świętych ${ }^{41}$. Podczas nabożeństw liturgicznych często powtarza się obrzęd okadzania ikon, wiernych i całej cerkwi. Ikony są także noszone w procesjach i udziela się nimi błogosławieństwa. Charakterystycznym przejawem czci obrazów jest też ustanawianie odrębnych świąt sławnych ikon, dotyczy to zwłaszcza ikon Bogurodzicy ${ }^{42}$. Cerkiew przewiduje specjalną modlitwę konsekracyjną, przez którą kapłan włącza ikonę w jej funkcję. Ikony uroczyście poświęca się i intronizuje podczas Boskiej Liturgii.

W sprawowaniu całego kultu Kościoła najważniejsza jest Osoba Chrystusa, Arcykapłana i Liturga. Wskazuje na to tematyka i rozmieszczenie ikon na ścianach świątyni, a przede wszystkim na ikonostasie. Ikona Chrystusa $\mathrm{z}$ arcykapłańskimi atrybutami zajmuje najważniejsze miejsce ponad wszystkimi innymi ikonami, które obrazują Ewangelię i żywoty świętych. W samym ikonostasie ikona Chrystusa będzie się nawet powtarzać kilkakrotnie w różnych jej typach ${ }^{43}$.

Pierwsze miejsce po wyobrażeniu Chrystusa zajmuje ikona Matki Bożej i tworzy wraz z nim harmonijną całość. Kościół widzi w Maryi Matkę Bożą i Orędowniczkę całej ludzkości ${ }^{44}$. Sławiąc Matkę Bożą, nie można nie sławić jej Syna. Tajemnica jej Bożego macierzyństwa wynika z tajemnicy wcielenia Boga. Ta więź utrwalona jest wyraźnie w ikonografii i w liturgii. W ikonostasie umieszcza się ikonę Maryi i Chrystusa na tej samej płaszczyźnie po obu stronach bramy królewskiej. Po prawej stronie znajduje się ikona Zbawiciela trzymającego w ręku Ewangelię - Słowo, które Bóg kieruje do człowieka. Po lewej Maryja wskazuje Dziecię trzymane na swej lewej ręce, ukazując światu żywe Słowo Boga (to typ ikony Hodegetria, czyli Wskazująca drogę). Chrystus i Bogurodzica spotykają nas w bramie królestwa Bożego i prowadzą ku zbawieniu przez całe życie.

\footnotetext{
4I Por. I. Alfeev, L'icona ..., dz. cyt., s. I37.

42 Por. A. Mień, Sakrament, stowo, obrzęd..., dz. cyt., s. 92-93.

43 Por. I. Jazykowa, Świat ikony, dz. cyt., s. 76-82.

44 „Miłość i kult Matki Bożej są duszą prawosławnej pobożności, sercem ogrzewającym i ożywiającym całe ciało... Kościół prawosławny jakby jednym tchem przyzywa najświętsze imię Jezus wraz z najsłodszym imieniem Maryja i nie rozdziela Ich w swojej miłości” (S. Bułgakow, Prawosławie, Białystok 1992, s. I32).
} 
Ikony Chrystusa i Bogurodzicy stanowią nieodłączny element liturgii eucharystycznej. Prawosławny kapłan nie odważyłby się sprawować Liturgii bez obecności tych dwóch ikon. Modlitwa przed tymi dwoma ikonami i przed bramą królewską ikonostasu (ros. carskie worota) jest pierwszym aktem liturgicznym, jeszcze przed rozpoczęciem proskomidii i właściwej Liturgii Bożej. Po odmówieniu troparionów pokutnych kapłan z diakonem stają przed ikoną Chrystusa, wykonują pokłon, a następnie proszą Chrystusa o darowanie win oraz dziękują za dzieło zbawcze ${ }^{45}$ :

Oddajemy pokłon Twemu przeczystemu obrazowi, Chryste Boże, prosząc o odpuszczenie naszych win. Bo Ty raczyłeś z własnej woli wejść na krzyż, aby wyrwać Twoje stworzenia z niewoli wroga. Dlatego z wdzięcznością wołamy do Ciebie: Zbawicielu nasz, wszystko napełniłeś radością, przychodząc, aby zbawić świat ${ }^{4}$.

Następnie całują ikonę Zbawiciela i przechodzą na drugą stronę świętych drzwi, do ikony Bogurodzicy. Pozdrawiają ją i zwracają się do Maryi jako do „źródła miłosierdzia”, prosząc, aby zlitowała się nad nami i okazała swoje mocne wstawiennictwo u Boga 47 :

Bogurodzico, Zdroju miłosierdzia, uczyń nas godnymi Twej łaskawości. Wejrzyj na lud, który zgrzeszył, okaż jak zawsze moc Twoją. W Tobie bowiem nadzieję pokładając, wołamy do Ciebie tak, jak niegdyś Archanioł Gabriel: Bądź pozdrowiona ${ }^{48}$.

Po ucałowaniu ikony stają przed królewską bramą ikonostasu, pochylają głowy, a kapłan sam odmawia końcową modlitwę tego wstępnego obrzędu, w której prosi o umocnienie, aby mógł godnie celebrować Liturgię:

Panie, poślij Twoją rękę z wysokości (miejsca) Twego przebywania i umocnij mnie do Twojej służby, która mam sprawować, abym mógł stanąć bez winy

\footnotetext{
45 Por. J. Czerski, Boska Liturgia św. Jana Chryzostoma, Opole 1998, s. 59 (Opolska Biblioteka Teologiczna, 28).

$4^{6}$ J. Czerski, Boska Liturgia św. Jana Chryzostoma, dz. cyt., s. 59.

47 Por. J. Czerski, Boska Liturgia św. Jana Chryzostoma, dz. cyt., s. 59.

$4^{8}$ J. Czerski, Boska Liturgia św. Jana Chryzostoma, dz. cyt., s. 59.
} 
przed Twoim ołtarzem i celebrować bezkrwawe święte obrzędy. Bo Twoja jest potęga i chwała, na wieki wieków. Amen ${ }^{49}$.

Ta modlitwa jest najstarszą spośród wszystkich modlitw przygotowawczych, znana była już w XI wieku i odmawiano ją kiedyś na początku proskomidii. Proskomidia - czyli przygotowanie darów chleba i wina do Eucharystii - jest pierwszą, wstępną częścią Liturgii Bożej i odbywa się w tzw. żertwienniku, po lewej stronie od ołtarza. Ściany żertwiennika często bywają ozdobione przedstawieniami różnych ofiar Starego Testamentu, zapowiadających bezkrwawą Ofiarę Chrystusa. Cząstki prosfor układane są na diskosie (patena) w sposób, który przypomina układ ikon w ikonostasie ${ }^{50}$.

W czasie trwania proskomidii do cerkwi przybywają wierni. Gromadząc się w świątyni na Eucharystię, wiedzą, że są tu oczekiwani. Nie wchodzą do pustego, zimnego kościoła, ale do miejsca świętego, pełnego Bożej obecności. Całują z uszanowaniem ikonę danego święta umieszczoną na anałoju (specjalny stolik na ikonę) na środku cerkwi, a także zapalają świece przed wizerunkami świętych, których szczególnie chcą prosić o wstawiennictwo. Dzięki ikonie dokonuje się tu tajemnica świętych obcowania, kontemplacja Trójjedynego Boga przez tych wszystkich, którzy tworzą Kościół ${ }^{51}$ Ikona nie tylko pomaga się modlić, ale jest także ,kanałem” łaski, którą Bóg zsyła na modlącego się przed nią człowieka.

Wielkie błaganie (ektenia) ${ }^{52}$, którym rozpoczyna się Eucharystia, to trzykrotna prośba, którą Kościół ziemski i niebieski zjednoczonym głosem kieruje do Boga o obdarzenie pokojem całego świata. Następnie odbywa się ryt, zwany „małym wejściem”, królewska brama otwiera się, podobnie jak królestwo Boże na przyjście Jezusa. Kapłan uroczyście niesie Ewangelię, a modlitwa, którą kieruje do Boga, odsłania tajemnicę dokonującego się misterium:

Władco, Panie i Boże nasz! Ty ustanowiłeś na niebiosach zastępy i wojska aniołów, i archaniołów, aby sprawowali liturgię ku Twej chwale, spraw, aby z naszym wejściem dokonało się wejście świętych aniołów, sprawujących wraz

\footnotetext{
49 J. Czerski, Boska Liturgia św. Jana Chryzostoma, dz. cyt., s. 60.

5o Por. szerzej A. Mień, Sakrament, słowo, obrzęd..., dz. cyt., s. 48-49.

${ }^{51}$ Por. A. Jacyniak, Okno do wieczności, „Miejsca Święte” 2000 nr I2 (48), S. 2I.

${ }_{52}$ Podczas Eucharystii wierni kilkakrotnie zwracają się do Boga w ekteniach, czyli seriach próśb wypowiadanych przez kapłana lub diakona w imieniu zgromadzenia. Są one przeplatane śpiewami oraz fragmentami biblijnymi (przede wszystkim psalmami), a także modlitwami cichymi, wypowiadanymi przez kapłana.
} 
z nami liturgię i współsławiących Twoją dobroć. Albowiem Tobie przystoi wszelka chwała, cześć i uwielbienies3.

Aniołowie, wyobrażeni m.in. na bocznych drzwiach diakońskich ikonostasu, włączają się do sprawowanej na ziemi liturgii, uczestniczą w modlitwie zgromadzonych w świątyni. Modlą się z nimi i za nich. Do tego nurtu modlitwy dołączają też święci, prorocy, patriarchowie, których postacie, przedstawione $\mathrm{w}$ kolejnych rzędach ikonostasu, niemal dosłownie otaczają ołtarz, ,sprawując liturgię” razem z kapłanem.

Ważną rolę w tworzeniu modlitewnej jedności odgrywa także, spowijający całą świątynię, dym kadzidła. Celebrans okadza całą cerkiew: ołtarz, ikony, zebranych wiernych. Ojciec Kwiatkowski tak opisuje ten obrzęd:

Gdy zapach kadzidła dotarł do moich nozdrzy, poczułem, że głosy śpiewających, lampki oliwne, twarze z ikon, migotanie złota spoiły się w organiczną jedność, a cała świątynia stała się modlitwą. Czułem, że w tej modlitwie uczestniczą również wszyscy ci, którzy odeszli, którzy budowali tę świątynię... Modlitwa zdawała się obejmować cały kosmos, którego miniaturą stawała się świątynia ${ }^{54}$.

Małe wejście to nie tylko wejście aniołów. To również „wejście” Ewangelii do serc wszystkich wiernych. Wołanie prezbitera, unoszącego w górę księgę słowa Bożego: „Oto Mądrość”, oznacza, że Ewangelia jest najwyższą mądrością, boską i objawioną, która nieskończenie przekracza ludzką wiedzę. Takie przedstawienie wiernym Ewangelii jest wezwaniem do słuchania i wypełniania słów Chrystusa. Wierni, słuchając słów Ewangelii, kontemplują także ikonę danego święta. „Słowo pisane” i „słowo malowane” łączą się razem w jeden głos Boga przemawiającego na różne sposoby do człowieka. Ewangeliarz pozostanie na ołtarzu do końca liturgii. Na ołtarzu zostaną też złożone Święte Dary (chleb i wino przemienione w Ciało i Krew Chrystusa). W ten sposób podkreślona jest nierozłączność niebieskiego pokarmu - słowa Bożego oraz Ciała i Krwi Pańskiej55.

Liturgia eucharystyczna, zwana „liturgią wiernych”, rozpoczyna się uroczystą procesją „,wielkiego wejścia”, w której wnoszone są na ołtarz dary

\footnotetext{
53 J. Czerski, Boska Liturgia św. Jana Chryzostoma, dz. cyt., s. 87.

54 Z. Kwiatkowski, Pielgrzymka na Górę Athos, „Posłaniec Serca Jezusowego” I999 nr II (I28), s. I4.

55 Por. Mnich Kościoła Wschodniego, Ofiara liturgiczna, Kraków I999, s. 26.
} 
chleba i wina. Chór wykonuje hymn Cherubikon. Do tego śpiewu i obrzędu bezpośrednio nawiązują ikony Liturgia niebieska i Liturgia świętych ojców (zostaną omówione w ostatniej części artykułu). Do sprawowanego misterium włączają się też inne ikony i cała świątynia wypełniona wiernymi. W pełnych poezji słowach, opisuje ten moment Paul Evdokimov, podkreślając rolę, jaką w tym liturgicznym misterium pełni ikona:

Od rozpoczęcia pieśni Cherubińskiej „Którzy Cherubinów mistycznie przedstawiamy i Trójcy Ożywicielce trzykroć święty hymn śpiewamy” wkraczamy rzeczywiście w Boską liturgię. Chrystus w asyście aniołów o niezliczonych oczach i miliardach szumiących skrzydeł i cała Boska Trójca uczestniczy w misterium, do którego zostają włączeni też ludzie, stając się żywym obrazem Cherubinów. Liturgia ziemska jest ikoną liturgii niebiańskiej, a ludzie są ikonami anielskiego służenia, adoracji i modlitwy. Wszystko staje się udziałem i obecnością. W tej wspaniałej całości wierny zapatrzony w Boskie misterium widzi swych przodków, apostołów, męczenników i świętych obecnymi i razem z nimi uczestniczy w niebiańskim eonie. Pełniąc wspólną służbę z aniołami, śpiewa on Ducha Piękności: „W twych świętych ikonach kontemplujemy niebiańskie przybytki, będąc uniesieni świętą radością" (z oficjum pierwszej niedzieli Wielkiego Postu) ${ }^{56}$.

Centralną modlitwą Eucharystii jest anafora, modlitwa dziękczynienia za wszelkie Boże dary. W tej wielkiej modlitwie Kościoła przywoływany jest ewangeliczny obraz Wieczerzy Pańskiej, powtarzane są słowa ustanowienia sakramentu Eucharystii. Unosząc Święte Dary, kapłan modli się o zstąpienie Ducha Świętego na Kościół i na jego dary, aby swoją boską mocą przemienił je w Ciało i Krew Pańską. Prezbiterium świątyni staje się jednocześnie Wieczernikiem i Golgotą ${ }^{57}$.

Następnie kapłan wspomina tych, na których w sposób widoczny objawiła się Pięćdziesiątnica: patriarchów i proroków, apostołów i ewangelistów, męczenników, ascetów i wszystkich sprawiedliwych, którzy spoglądając z ikon, modlą się razem z pielgrzymującym Kościołem. Nade wszystko wspominana i wychwalana jest Theotokos, Matka Boża i nasza Matka w hymnie Dostojno jest (Godne to...)..$^{58}$

\footnotetext{
${ }^{6} \quad$ P. Evdokimov, Prawostawie, dz. cyt., s. 288.

57 Por. A. Mień, Sakrament, słowo, obrzęd..., dz. cyt., s. 6I.

$5^{8}$ „Godne to i sprawiedliwe błogosławić Cię, Bogarodzico, zawsze błogosławioną i przeczystą, i Matkę naszego Boga. Wysławiamy Ciebie, czcigodniejszą od Cherubinów i sławniejszą
} 
Podsumowaniem i wynikiem anafory jest obrzęd Komunii świętej. Ikona Wieczerzy Pańskiej, która znajduje się nad królewską bramą ikonostasu, jest liturgiczną anamnezą Wieczernika (omówiona poniżej). Dopomaga każdemu wiernemu w świadomym przeżyciu osobistego spotkania z Jezusem w Komunii.

Liturgia każdego dnia, a szczególnie niedzieli i święta, daje człowiekowi okazję do stanięcia przed Bogiem z całym ciężarem codziennego życia. Dla wiernych, którzy w przededniu niedzieli czy święta pragną przygotować się do godnego przeżycia świątecznej liturgii, cerkiew stoi otworem (przede wszystkim w miastach ${ }^{59}$. Wierni mogą włączyć się w poszczególne części liturgii godzin, która w Kościele wschodnim zachowała charakter wspólnotowy. Podczas tzw. całonocnego czuwania ${ }^{60}$ spektakularny charakter ma wygaszanie i zapalanie wszystkich świec w cerkwi, także przed ikonami. $\mathrm{Na}$ jutrzni (ros. utlenia) wielkich świąt prawosławia oddaje się szczególną cześć ikonie celebrowanego święta. Jak już wspomiano, ikona wystawiona jest na specjalnym podwyższeniu zwanym anałojem, znajdującym się na środku cerkwi i przed nią właśnie odprawia się liturgię godzin danego święta.

Największym osiągnięciem i prawdziwym skarbem liturgii bizantyjskiej są nabożeństwa Wielkiego Tygodnia i Paschy. Pascha jest centrum całego roku liturgicznego, jest „świętem świąt”. Paschę poprzedzają cztery niedziele pokutne oraz Wielki Post. Trzy ostatnie dni Wielkiego Postu to wspomnienie ustanowienia Eucharystii (Wielki Czwartek), misterium cierpienia i śmierci Chrystusa (Wielki Piątek) i obrzęd pogrzebu Zbawiciela, będący szczytem twórczości liturgicznej prawosławia (Wielka Sobota).

Podczas wieczornego nabożeństwa Wielkiego Piątku wynoszona jest na środek cerkwi ikona Chrystusa w grobie, tzw. płaszczanica. Wierni przy-

bez porównania od Serafinów, która nieskazitelnie rodzisz Boga Słowo i jesteś Bogarodzicą" (cyt. za: J. Czerski, Boska Liturgia św. Jana Chryzostoma, dz. cyt., s. 136). Por. Mnich Kościoła Wschodniego, Ofiara liturgiczna, dz. cyt., s. 5I.

59 Por. A. Mień, Sakrament, słowo, obrzęd..., dz. cyt, s. 30-38.

60 W liturgii wschodniej podtrzymywana jest starożytna tradycja, z przełomu III i IV wieku, wieczornego czuwania na modlitwie w świątyni. Jest to tak zwana wieczernia (nieszpory), nabożeństwo z bogato rozbudowaną liturgią wprowadzającą $\mathrm{w}$ misterium danego święta. W święta Bożego Narodzenia i Wielkanocy, a w niektórych monasterach również w inne dni świąteczne, wieczernia łączona była z modlitwami, które trwały aż do rana. Chociaż współcześnie takie całonocne nabożeństwa należą do rzadkości, wieczernia połączona z modlitwą poranną (utrenia) zachowała nazwę całonocnego czuwania. Zob. A. Mień, Sakrament, słowo, obrzęd..., dz. cyt., s. 35 . 
chodzą z uczuciem bojaźni i ze łzami oraz kłaniają się i całują ikonę $e^{61}$ W Wielką Sobotę ikona ta obnoszona jest trzykrotnie wokół świątyni jak podczas pogrzebu. Zostaje następnie wniesiona za ikonostas i położona na ołtarzu. $\mathrm{Na}$ niej będzie sprawowana Eucharystia przez cały okres wielkanocny ${ }^{62}$. O północy królewska brama ikonostasu zostaje otwarta i kapłani ze świecami idą przez rozświetloną cerkiew. W rękach wiernych i przed wszystkimi ikonami płoną świece i lampki oliwne. Szczególnie wyakcentowana jest ikona Zmartwychwstania Pańskiego, która już od liturgii całonocnego czuwania (ros. wsienoszcznoje biednie) znajduje się na środku cerkwi. Całą świątynię wypełnia śpiew:

Zmartwychwstanie Twoje, Chryste Zbawco, aniołowie opiewają na niebiosach, a nas na ziemi uczyń godnymi sławić Ciebie czystym sercem ${ }^{63}$.

Święto Paschy oplata dwanaście wielkich świąt Kościoła prawosławnego jak korona obrazów ${ }^{64}$, z których każdy wyraża główne prawdy wiary. Dwanaście ikon świąt, zwanych prazdnikami zajmują cały osobny rząd w ikonostasie. Ikony „oświetlają” liturgiczne wydarzenia celebrowane w ciągu całego roku kościelnego i razem z obrzędami, tekstami liturgicznymi tworzą jedną całość w głoszeniu misterium. Jazykowa tłumaczy tę liturgiczną jedność w następujący sposób w oparciu o teologię słowa Bożego:

Podstawą liturgii jest słowo Boże. W liturgii prawosławnej postrzegamy jakby rozliczne hipostazy słowa: słowo dźwięczące (czytanie Ewangelii i Apostoła, modlitwy, kazanie, śpiew), słowo ujawnione wzrokowi (freski, mozaiki, ikony), a w końcu Słowo, Bóg Żywy, obecny pośród ludu zgromadzonego w Jego imię i przez komunię stającego się Jego Ciałem, Ciałem Chrystusa ${ }^{65}$.

Ikona rodzi się z liturgii i tak samo jak liturgia jest wtajemniczeniem w Boga. Nie istnieje w oderwaniu od słowa, muzyki, poezji, gestu liturgicz-

\footnotetext{
6r S. Bułgakow, Prawostawie, dz. cyt., s. I47-I48.

62 O związku tego zwyczaju liturgicznego z zachodnią tradycją Bożego Grobu pisał o. Franciszek Małaczyński. Zob. F. Małaczyński, Bizantyskie i tacińskie wpływy na liturgię Bożego Grobu, „Ruch Biblijny i Liturgiczny” 2-6 (I992), s. 90-93.

63 S. Bułgakow, Prawostawie, dz. cyt., s. I48.

64 M. Quenot, Ikona. Okno ku wieczności, Białystok 1977, s. 44.

65 I. Jazykowa, Świat ikony, dz. cyt., s. 42.
} 
nego ${ }^{66}$. Podczas liturgii „przemawia” najpełniej i spełnia swoją najważniejszą funkcję. W ogólnym przedstawieniu ważniejszych celebracji mogliśmy się przekonać, że ikony biorą w nich aktywny udział, tworząc razem z celebransami i wiernymi szczególną, liturgiczną koinonię - wspólnotę, przekraczającą granice widzialnego świata. Dobrze wyrażają to słowa Aleksandra Schmemana:

W niektórych starych cerkwiach ikony jakby uczestniczą w zgromadzeniu Kościoła, wyrażają jego sens, nadają mu odwieczny ruch i rytm. Wespół ze wszystkimi czynami proroków, apostołów, męczenników i hierarchów, cały Kościól, całe zgromadzenie jakby wstępuje na niebiosa, tam, dokąd je prowadzi i podnosi Chrystus, do swego Stołu, w Jego Królestwie ${ }^{67}$.

\section{LITURGIA NA IKONIE}

Cerkiew, gdy sprawowana jest w niej liturgia, staje się wymownym symbolem nowej rzeczywistości, przyszłości nowej ziemi i nowego nieba. Kościół gromadzi się w świątyni na liturgii, aby uczestniczyć w tej wizji przyszłego świata i uświęcając się wkraczać już dzisiaj w królestwo Boże. Bez wątpienia materialny budynek świątyni jest nie tylko miejscem zgromadzenia, ale i znakiem żywej wspólnoty Kościoła. Tę bogatą symbolikę świątynia wyraża już, jak to pokazaliśmy wyżej, przez swoją architekturę i ikonografię. Najwięcej ,mają tu do powiedzenia" ikony, wypełniając właściwą im teologiczną i liturgiczną funkcję. Liturgia miała niebagatelny wpływ na ustalenie ścisłych kanonów ich wykonania oraz podejmowaną przez nie tematykę. Archimandryta Zinon podkreśla, że w szerszym rozumieniu każda ikona jest ściśle związana z liturgią:

Ikona jest zakorzeniona w eucharystycznym doświadczeniu Cerkwi, jest z nim nierozerwalnie związana, podobnie zresztą jak z ogólnym poziomem życia religijnego. Kiedy ten poziom był wysoki, to i sztuka cerkiewna była na wysokości;

\footnotetext{
66 Por. M. Quenot, Ikona..., dz. cyt., s. 3.

${ }_{67}$ A. Schmemann, Eucharystia. Misterium Królestwa, Białystok I983, s. I4.
} 
kiedy zaś życie religijne słabło lub też następowały czasy jego upadku - wtedy następował też upadek sztuki cerkiewnej ${ }^{68}$.

Nie miejsce tu na przedstawienie całej tej historii, przeanalizował ją bardzo wnikliwie ojciec Leonid Uspienski w klasycznym już dziele Teologia ikony, a Irina Jazykowa ukazała najnowsze dzieje ikony i jej odrodzenie w XX wie$\mathrm{ku}^{69}$. Zwrócimy jedynie uwagę na ciekawe zjawisko pojawienia się na ikonach tematyki sensu stricto liturgicznej.

Od IX do XI wieku formują się oficjalne reguły ustalające ikonograficzny program cerkwi. Cerkwie XI wieku ukazywały hierarchicznie uporządkowany kosmos, kierowany przez Chrystusa, aniołów i świętych. Ikony miały przedstawić misterium Chrystusa w jego całości i uczynić je obecnym w liturgicznym życiu Kościoła, ilustrując różne wydarzenia zbawcze. W ten sposób obrazy wyrażały prawdę, że to Kościół jest miejscem, gdzie uobecnia się misterium. Ikony pomagały uczynić je obecnym, wspierały liturgiczną anamnezę ${ }^{70}$. Z czasem ten cykl obrazów misteriów zbawczych został włączony w oddzielny rząd ikonostasu, który tworzą ikony zwane prazdnikami, a sama liturgia znalazła swoją oddzielną ekspresję poza tym cyklem. Pojawiły się nowe tematy liturgiczne. Te tematy odegrają najważniejszą rolę w późnobizantyjskiej ikonografii. Wśród nich pierwsze miejsce zajmują tematy eucharystyczne - Komunia apostołów, Liturgia ojców Kościoła, Liturgia niebieska. Te obrazy-ikony wyrażają już religijne spekulacje i doświadczenie mistyczne, które normalnie miało swoje źródło w przeżyciu liturgicznym (stąd ahistoryczność przedstawień) ${ }^{71}$.

Przyjrzyjmy się, jak ostatecznie przedstawia się ikonograficzna tematyka wschodniej świątyni, która - jak widać - ściśle związała się ze sprawowaną w jej wnętrzu liturgią ${ }^{72}$. Centralne miejsce w wielkiej kopule cerkwi zajmuje ikona Chrystusa Pantokratora, Pana Kosmosu ${ }^{73}$. Całe sklepienie jest ikoną nieba, dokąd Chrystus wstąpił i skąd ma przyjść na końcu czasów. Świątynia jest miejscem oczekiwania na przyjście Zbawiciela. Wierni zgromadzeni

\footnotetext{
68 Archimandrit Zinon (Teodor), Biesiedy ikonopisca, dz. cyt., s. I29.

69 L. Uspenski, Teologia ikony, Poznań I993, passim; I. Jazykowa, Oto czynię wszystko nowe..., dz. cyt., passim.

70 Por. H.-J. Schulz, The Byzantine Liturgy, New York 1986, s. 78-79.

${ }_{71}$ Por. H.-J. Schulz, The Byzantine Liturgy, dz. cyt., s. IOI-I02.

72 Por. P. Nowakowski, Liturgiczna funkcja ikony..., dz. cyt., s. 315-320.

73 Zob. szerzej S. Barbagallo, Iconografia liturgica del Pantocrator, Roma I996 (Studia Anselmiana. Analecta liturgica, 22).
} 
pod kopułą, wpatrują się w postać Chrystusa, wokół której z kolei gromadzi się cały dwór niebieski, aniołowie i święci. Duchowa łączność nieba z ziemią urzeczywistnia się podczas liturgii. To Chrystus - Najwyższy Kapłan sprawuje niebieską liturgię w otoczeniu cherubinów i serafinów. Aniołowie przedstawiani bywają często $\mathrm{w}$ szatach liturgicznych - kapłańskich i diakońskich, niosą świeczniki, rypidy i naczynia liturgiczne. Od XIV wieku umieszczanie tej ikony (Liturgia niebieska), zainspirowanego hymnem Cherubikon i procesją wielkiego wejścia Liturgii Bożej, stanie się obowiązkowe w budynku cerkwi, najczęściej właśnie na kopule ${ }^{74}$.

Chrystus Pantokrator wyciąga prawicę w geście liturgicznego błogosławieństwa (palce ułożone są jak w błogosławieństwie kapłańskim obrządku bizantyjskiego), aby przypomnieć, że nie przyszedł na świat po to, by potępiać, ale zbawiać. W lewej dłoni trzyma Ewangelię, co oznacza, że zawsze można Go odnaleźć w Jego Słowie ${ }^{75}$. Chrystusa otaczają aniołowie oraz cztery tajemnicze istoty - symbole czterech Ewangelii (orzeł, byk, lew i człowiek). Całe pozostałe stworzenie, wyobrażone często na kolumnach i ścianach cerkwi, kieruje się ku otwartej ręce Króla, który władczym ruchem porządkuje całość i kieruje ku liturgicznemu sercu cerkwi-ikonie Uczty Pańskiej ${ }^{76}$. Zdobiła ona kiedyś ściany prezbiterium, gdzie sprawowana jest Eucharystia, a z czasem umieszczona została nad bramą królewską ikonostasu.

Ikona Uczty Pańskiej, ukazująca tajemnicę Eucharystii, ma swoje dwie wersje: Ostatnia wieczerza i Komunia apostołów. Ostatnia wieczerza jest historycznym przedstawieniem wydarzeń z wieczernika, podczas gdy Komunia apostołów daje jego liturgiczną interpretację. Ta bezpośrednio eucharystyczna tematyka pojawiła się w ikonografii dopiero po ostatecznym zwycięstwie nad ikonoklazmem ${ }^{77}$. Na ikonie Komunia apostołów Chrystus stojący przy ołtarzu i ubrany w szaty kapłańskie, udziela apostołom Komunii na sposób liturgiczny. Hans-Joachim Schulz tak komentuje to przedstawienie:

Ta ikonografia wyraźnie przekracza granicę między widzialnym i niewidzialnym, między czasem i wiecznością, daje wyraz mistycznego doświadczenia jedności obydwu ${ }^{78}$.

\footnotetext{
74 Por. H.-J. Schulz, The Byzantine Liturgy, dz. cyt., s. III-II3.

75 Por. J. Forest, Modlitwa z ikonami, Bydgoszcz I999, s. 93-94.

76 Por. P. Evdokimov, Sztuka ikony. Teologia piękna, Warszawa 1999, s. 139-I40.

77 Por. Ch. Walter, Sztuka i obrządek Kościoła bizantyńskiego, thum. K. Malcharek, Warszawa I992, S. 208-2II.

${ }_{78}$ H.-J. Schulz, The Byzantine Liturgy, dz. cyt., s. I03.
} 
Według wspomnianego autora bowiem obraz ten pokazuje liturgię Cerkwi na ziemi, która jest równocześnie ,ikoną” liturgii niebieskiej, ponieważ aktualnie biorą w niej udział także sam Chrystus i apostołowie ${ }^{79}$.

Kolejną ikoną, par exellence liturgiczną, jest Liturgia świętych ojców, należąca $\mathrm{w}$ do ikonograficznego programu apsydy. Centralnie umiejscowiony Chrystus w stroju patriarchy wschodniego stoi za ołtarzem, a ku Niemu z obydwu stron kierują się postacie apostołów, świętych ojców Kościoła (wśród nich twórców liturgii), biskupów w szatach liturgicznych. Wśród tego orszaku w ikonografii bizantyjskiej znajdziemy także osoby cesarza i cesarzowej, reprezentujące ziemski świat ${ }^{80}$. Niektóre przedstawienia przypominają przygotowanie Baranka (Agnca) w czasie proskomidii lub łamanie prosfory przed Komunią, na co wyraźnie wskazuje czasami umieszczony na ikonie napis melismos (gr. tamanie chleba) ${ }^{81}$. W innych wypadkach scena ta przybiera postać „wielkiego wejścia” i łączy się tematycznie z drugą ikoną Liturgii niebieskiej. Tutaj biskupi już razem z aniołami niosą dary, paramenty i naczynia liturgiczne. Biskupi podchodzący do Chrystusa od strony diakonikonu trzymają w rękach zwoje zapisane pierwszymi słowami modlitw liturgii ${ }^{82}$. W ten sposób cały Kościół niebieski i ziemski gromadzi się wokół Chrystusa celebrującego wieczną liturgię.

Kiedy rozwijający się ikonostas zasłonił przed oczami wiernych malowidła ścian apsydy, ikonę Ostatniej wieczerzy umieszczono nad królewską bramą. Pod tą ikoną wierni jednoczą się z Chrystusem w Komunii świętej.

Do dekoracji apsydy dość wcześnie wprowadzono także wizerunki świętych. Aby właściwie ukierunkować ich kult, zostaje on włączony do liturgii eucharystycznej i rozwinięty w formie wstawienniczej ${ }^{83}$. Wstawiennictwo wywodzi się z adoracji skupiającej się wokół osoby Matki Boskiej i Chrystusa. Matka Boża ukazywana jest w niszy apsydy, stanowiąc „most” między niebem i ziemią, jako ta, która wskazuje drogę swym dzieciom i doprowadza je do źródła życia - Eucharystii.

Cały, bogaty w liturgiczną treść program ikonograficzny apsydy przenosi się z czasem na ikonostas, który pojawił się na granicy prezbiterium i nawy cerkwi. Ikonostas z jednej strony oddzielił wiernych od ołtarza i przyczynił

\footnotetext{
79 Por. H.-J. Schulz, The Byzantine Liturgy, dz. cyt., s. I03-I04.

8o Por. Ch. Walter, Sztuka i obrzadek..., dz. cyt., s. 204-206.

${ }_{8 \mathrm{I}} \quad$ Por. H.-J. Schulz, The Byzantine Liturgy, dz. cyt., s. I05-III.

82 Por. Ch. Walter, Sztuka i obrzadek..., dz. cyt., s. 236-237.

${ }_{3}$ Por. Ch. Walter, Sztuka i obrzadek..., dz. cyt., s. 206-208.
} 
się do podziału Ludu Bożego na duchowieństwo i świeckich. Z drugiej jednak łączy on uczestników liturgii ze światem duchowym, pozwala przeżywać mistyczny wymiar liturgii, rzeczywistość królestwa Bożego na ziemi ${ }^{84}$. Ciekawe świadectwo z tym związane przytacza o. Špidlík:

Osoby, które nie znają wschodniej liturgii, pytają zwykle, dlaczego w kościołach bizantyjskich ołtarz oddzielony jest od reszty wnętrza szczególnym murem. Pewien turysta czynił z tego niemal zarzut po adresem rosyjskiego popa: Dlaczego skrywa się tutaj to, co odbywa się na oltarzu? Dlaczego nie wolno tego ogladać? Pop uśmiechnął się i rzekł: Ikonostas jest tutaj po to, żebyśmy na jego obrazach ujrzeli to, co w sposób niewidoczny dokonuje się na ottarzu ${ }^{85}$.

Ikonostas pełni bardzo ważną rolę w związaniu ikony z liturgią - w sensie prawie dosłownym wprowadza on ikony w liturgię, znajdując się w centrum jej sprawowania ${ }^{86}$.

Wszystkie świątynie chrześcijańskie budowano tak, aby część ołtarzowa znajdowała się na wschodzie. Wierny zwrócony twarzą ku ołtarzowi, gdzie sprawowana jest liturgia, patrzy w stronę wschodzącego słońca. Symbolizuje to zwrócenie się ku Chrystusowi, który jest „,nawiedzającym nas Słońcem wschodzącym z wysoka" (por. Łk I, 78).

$\mathrm{Na}$ ścianach bocznych i sklepieniach cerkwi umieszcza się, jak już wiemy, sceny z biblijnej historii zbawczej oraz sceny z historii Kościoła. Od końca XIII wieku rozpowszechnił się zwyczaj przedstawiania w nawach soborów ekumenicznych. Słuszne jest twierdzenie Christophera Waltera, że o ile tematy ikonograficzne apsydy spełniały funkcje ściśle doktrynalne i liturgiczne, o tyle tezy Kościoła ziemskiego lepiej było głosić w narteksie ${ }^{87}$. Odpowiada to zresztą ogólnej symbolice świątyni, w której część ołtarzowa (za ikonostasem) oznaczała niebo, a nawa rzeczywistość ziemską.

Całościowy program ikonograficzny cerkwi przedstawia obraz wszechświata. Malowidła są wykonywane w rzędach (dotyczy to fresków na ścianach i rozmieszczenia ikon na ikonostasie), co świadczy o hierarchicznym porządku całego stworzenia. Rząd najwyższy ukazuje wydarzenia z życia Chrystusa

\footnotetext{
${ }^{84}$ Na ten temat szerzej w: A. Schmemann, Eucharystia..., dz. cyt., s. I3-I4.

$8_{5}$ T. Špidlík, Dusza rosyjska, Poznań 2002, s. 24.

86 Więcej na temat ikonostasu zob. I. Jazykowa, Świat ikony, dz. cyt., s. 50-52; P. Evdokimov, Sztuka ikony..., dz. cyt., s. I35-I38; M. Quenot, Ikona..., dz. cyt., s. II4-II5; G. Krug, Myśli o ikonie, dz. cyt., s. 39-42.

${ }^{87}$ Por. Ch. Walter, Sztuka i obrzadek..., dz. cyt., s. 239-240.
} 
i Jego Matki. Nieco niżej znajdują się sceny ze Starego Testamentu. Patriarchowie i prorocy rozpoczynają ,pochód świętych”, w którym szczególne miejsce zajmują Joachim i Anna, Symeon i Jan Chrzciciel. Następnie „kroczą” apostołowie i ewangeliści, męczennicy, doktorzy i nauczyciele, a w końcu inni święci, którzy przyjęli przesłanie Ewangelii i skierowali swoje życie ku temu samemu celowi ostatecznemu ${ }^{88}$. Najniżej, wzdłuż całej cerkwi, wymalowane są wzory imitujące płótna dekoracyjne, które mają przypominać, że każda świątynia to jerozolimski Wieczernik, gdzie Chrystus spożył z uczniami ostatnią wieczerzę ${ }^{89}$.

W ten sposób cała przestrzeń wschodniej świątyni nastawiona jest na celebrację liturgiczną. Zawsze gotowa jest na sprawowanie liturgii, o której stale przypominają ikony, zwłaszcza te o ściśle liturgicznej tematyce:

W kościele w każdej chwili i nawet poza nabożeństwem wszystko znajduje się w oczekiwaniu na święte misteria, w oczekiwaniu na Eucharystię. Mocne uczucie nieustannego życia płynie z tej obecności, zastygłej jakby w dążeniu ku niebiańskiej liturgii ${ }^{\circ}$.

Podsumowując ukazany związek ikony i liturgii o podwójnej dynamice (ikona w liturgii - ikona na liturgii), można przytoczyć kolejny raz Evdokimova, który rozszerza liturgiczne oddziaływanie ikony także na życie i duchowość wiernych:

Formy architektoniczne świątyni, freski, ikony, przedmioty kultu nie są zgromadzone na zasadzie obiektów w muzeum, lecz, tak jak członki jednego ciała, żyją jednym tajemnym życiem, są włączone w tajemnicę liturgii. Stanowi to ich istotę i nigdy nie można zrozumieć ikony poza tym kontekstem. W domach wiernych ikonę umieszcza się wysoko, w głównym punkcie pomieszczenia: ona kieruje spojrzenia ku górze, ku Najwyższemu i ku temu, co jako jedyne jest potrzebne. Modlitewna kontemplacja jakby przechodzi przez ikonę, zatrzymując się jedynie na żywej treści, którą ikona wyraża. Przez swoją funkcję liturgiczną, symbiozę sensu i obecności, ikona uświęca czas i miejsce;

\footnotetext{
88 Por. N. Zernov, Wschodnie chrześcijaństwo, Warszawa 1967, s. 213.

89 Por. I. Jazykowa, Świat ikony, dz. cyt., 47.

90 P. Evdokimov, Prawostawie, dz. cyt., s. 289.
} 
z neutralnego mieszkania czyni kościół domowy, z życia wiernego - życie modlitewne, liturgię wewnętrzną i ciągłą ${ }^{1}$.

Na koniec wypada wyrazić życzenie i zachętę, by wszyscy zainteresowani sztuką ikony, zwracali zawsze uwagę na jej liturgiczny kontekst, co nie zawsze ma miejsce. Ten kontekst jest niezbędny, aby prawidłowo zgłębiać dziś znaczenie ikony, która jako niezaprzeczalne dziedzictwo i bogactwo Kościoła wschodniego bez wątpienia warta jest naszej uwagi oraz zasługuje na uczciwe, interdyscyplinarne i profesjonalne studium. Do takiego podejścia skłaniają słowa archimandryty Zinona:

Kościół prawosławny dysponuje bezcennym skarbem nie tylko w dziedzinie liturgii i dzieł Ojców Kościoła, ale także w dziedzinie sztuki sakralnej. Kult świętych ikon pełni w Cerkwi ważną rolę, ponieważ ikona jest czymś więcej niż po prostu obrazem. Nie tylko upiększa świątynię lub ilustruje Pismo Święte, ale w pełni odpowiada Pismu, jest organicznie zespolona z życiem liturgicznym [...]. Stąd zrozumiałe jest, że badanie treści i sensu ikony jest przedmiotem teologii tak samo jak studiowanie Pisma Świętego ${ }^{92}$.

\section{Bibliografia}

Alfeev I., L'icona. Arte, bellezza e mistero, Bologna 2017.

Barbagallo S., Iconografia liturgica del Pantocrator, Roma 1996 (Studia Anselmiana. Analecta liturgica, 22).

Bułgakow S., Prawostawie, Białystok 1992.

Bunge G., Lo Spirito Consolatore. Il significato dell'iconografia della Santa Trinità dalle catacombe a Rublev, Milano 1995.

Bux N., Tra cielo e terra. La mistica della liturgia orientale, Siena 2017.

Czerski J., Boska Liturgia św. Jana Chryzostoma, Opole 1998 (Opolska Biblioteka Teologiczna, 28).

\footnotetext{
91 P. Evdokimov, Sztuka ikony..., dz. cyt., s. I53.

92 Archimandrit Zinon, Ikona w liturgiczeskom wozrożdenii, ,Pamjatniki Oteczestwa. Był' monastyrskaja" 2-3 (I992), s. 57-58. Cyt. za: I. Jazykowa, Oto czynię..., dz. cyt., s. I22.
} 
Damasceński Jan, I Mowa obronna przeciw tym, którzy odrzucaja święte obrazy, thum. M. Dylewska, „Vox Patrum” I9 (I999) t. 36-37, s. 497-5I5.

Dejaiifve E., Les Icônes, Chevetogne 1962.

Evdokimov P., Prawostawie, Warszawa 1986.

Evdokimov P., Sztuka ikony. Teologia piękna, Warszawa 1999.

Florenski P., Ikonostas $i$ inne szkice, Warszawa 1984.

Forest J., Modlitwa z ikonami, Bydgoszcz I999.

Jacyniak A., Okno do wieczności, ,, Miejsca Święte” 2000 nr I2 (48), s. 2I-23.

Jazykowa I., Oto czynię wszystko nowe. Ikona w XX wieku, Warszawa 201 I.

Jazykowa I., Świat ikony, Warszawa 1988.

Krug G., Myśli o ikonie, Białystok I99I.

Kwiatkowski Z., Pielgrzymka na Górę Athos, „Posłaniec Serca Jezusowego” I999 $\mathrm{nr}$ II(I28), s. I4.

Małaczyński F., Bizantyskie i łacińskie wptywy na liturgię Bożego Grobu, „Ruch Biblijny i Liturgiczny” 2-6 (I992), s. 90-93.

Meyendorff J., Teologia bizantyjska, Warszawa I984.

Mień A., Sakrament, słowo, obrzęd. Prawostawna stużba Boża, Łuków 1992.

Mnich Kościoła Wschodniego, Ofiara liturgiczna, Kraków 1999.

Nowakowski P., Liturgiczna funkcja ikony w obrzadku bizantyjskim, „Liturgia Sacra" Io (20I4), s. 3I4-330.

Povest'vremennych let, red. A. Lichaczev, t. I, Moskva-Leningrad I930.

Quenot M., Ikona. Okno ku wieczności, Białystok 1977.

Schmemann A., Eucharystia. Misterium Królestwa, Białystok 1983.

Schulz H.-J., The Byzantine liturgy, New York 1986.

Špidlík T., Dusza rosyjska, Poznań 2002.

St Germanus of Constantinople, On the Divine Liturgy, Crestwood 1984.

Symeon Thessalonicensis Arhiepiscopus, De sacro ritu sancti olei, w: Symeonis Thessalonicensis Archiepiscopi Opera Omnia, tomus unicus, accurante J.-P. Migne, Parisiis I886, kol. 5I5-535 (Patrologiae Cursus Completus Series Graeca, I55).

Symeon Thessalonicensis Arhiepiscopus, De sacro templo et eius consecratione, w: Symeonis Thessalonicensis Archiepiscopi Opera Omnia, tomus unicus, accurante J.-P. Migne, Parisiis I886, kol. 305-36I (Patrologiae Cursus Completus Series Graeca, I55).

Taft R., Liturgia. Wzór modlitwy, ikona życia, Warszawa 2010.

Taft R., Ponad wschodem i zachodem. Problemy rozumienia liturgii, Kraków 2014.

Trubeckoi E., Contemplazione nel colore. Tre studi sull'icona russa, Milano I988. 
Uspenski L., Teologia ikony, Poznań 1993.

Walter Ch., Sztuka i obrządek Kościoła bizantyńskiego, Warszawa 1992.

Ware K., Kościót prawosławny, Białystok 2002.

Zernov N., Wschodnie chrześcijaństwo, Warszawa 1967.

Zinon Archimandrit (Teodor), Biesiedy ikonopisca, Riga 1997.

Zinon Archimandrit (Teodor), Ikona w liturgiczeskom wozrożdenii, „Pamjatniki Oteczestwa. Był' monastyrskaja” 2-3 (1992), s. 57-63.

\section{SUMMARY}

\section{The icon in liturgy, liturgy on the icon. The icon in liturgical space}

The article presents the position of icon in the sacred space of the Orthodox church and its function in liturgy of the Byzantine rite. In the beginning a rich theology of icon was outlined and its importance in Eastern tradition. In the Eastern Church the icon is considered as a window to heaven, a special sacrament of God's presence Christ, Mary and saints among the people. Equally important is the role of illustrating and revealing a dogma, a didactic explanation of the Church's teaching to the faithful. These functions the icon plays mostly within the temple, mainly during liturgy, which celebrated on the earth is also considered as an image - an icon of celestial liturgy. Through the article a reader is made familiar with the iconographic plan of the church and the arrangement of the icons according to the strictly observed pattern. It becomes more comprehensive in the context of liturgical action, when the icon plays a very important role. For that reason the particular parts of Divine Liturgy (Eucharist) are described with regard to the role of icons within the celebration. Eventually the paper presents several icons of a strictly liturgical character, that have started to appear within the church since the $9^{\text {th }}$ century. Finding a right place within the sacred space, the icons have affirmed their liturgical flavour and assured about their exceptional meaning in life, liturgy and ecclesial spirituality of the Byzantine rite. 
4. Uniwersytet Papiesk

(T) Jana Pawla II 